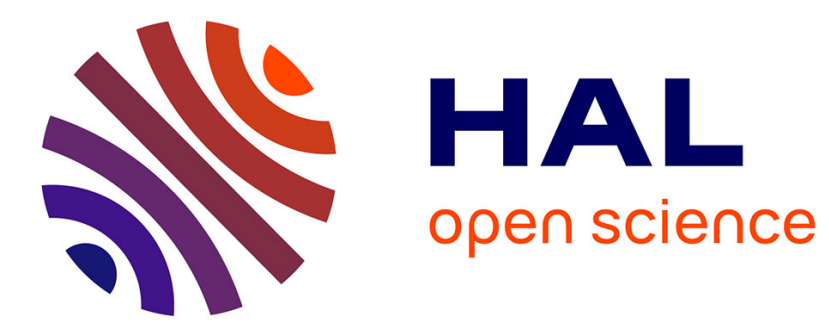

\title{
EXAFS Study of the Nature of Zinc Complexation Sites in Humic Substances as a Function of Zn Concentration
}

\author{
G. Sarret, A. Manceau, J. Hazemann, A. Gomez, M. Mench
}

\section{To cite this version:}

G. Sarret, A. Manceau, J. Hazemann, A. Gomez, M. Mench. EXAFS Study of the Nature of Zinc Complexation Sites in Humic Substances as a Function of Zn Concentration. Journal de Physique IV Proceedings, 1997, 7 (C2), pp.C2-799-C2-802. 10.1051/jp4:1997239 . jpa-00255318

\section{HAL Id: jpa-00255318 https://hal.science/jpa-00255318}

Submitted on 1 Jan 1997

HAL is a multi-disciplinary open access archive for the deposit and dissemination of scientific research documents, whether they are published or not. The documents may come from teaching and research institutions in France or abroad, or from public or private research centers.
L'archive ouverte pluridisciplinaire HAL, est destinée au dépôt et à la diffusion de documents scientifiques de niveau recherche, publiés ou non, émanant des établissements d'enseignement et de recherche français ou étrangers, des laboratoires publics ou privés. 


\title{
EXAFS Study of the Nature of Zinc Complexation Sites in Humic Substances as a Function of Zn Concentration
}

\author{
G. Sarret*, A. Manceau*, J.L. Hazemann*, A. Gomez** and M. Mench** \\ * Environmental Geochemistry Group, LGIT-IRIGM, University of Grenoble and CNRS, BP. 53, 3804I Grenoble, cedex, \\ France
}

** INRA, Unité de Recherches en Agronomie, Centre de Bordeaux, BP. 81, 33883 Villenave d'Ornon cedex, France

\begin{abstract}
Humic substances are known to play a key role in the immobilisation of metals in soils. The main complexing ligands that are supposed to interact with metals are carboxylic and phenolic. The complexation mechanism of zinc by two natural humic acids ( $T$ and $F$ ) was studied by EXAFS spectroscopy at the $\mathrm{Zn}-\mathrm{K}$ edge over a wide range of zinc concentration. The ligation mechanism of $\mathrm{Zn}$ was found to vary with the metal concentration and the nature of the humic acid. As $\mathrm{Zn}$ concentration is raised, the amplitude of EXAFS spectra decreases, which is interpreted as an increased distribution of ligand sites. At low $\mathrm{Zn}$ concentration $(300-5000 \mathrm{mg} / \mathrm{Kg}$ ), zinc forms inner sphere complexes in octahedral coordination for $\mathrm{T}$ humic acid, and in octahedral and tetrahedral coordinations for $\mathrm{F}$ humic acid. At intermediate $\mathrm{Zn}$ concentration ( $32 \mathrm{~g} / \mathrm{Kg}$ ), a large number of different sites are observed and only octahedral coordination is detected. At high $\mathrm{Zn}$ concentration $(500 \mathrm{~g} / \mathrm{Kg})$, most $\mathrm{Zn}$ forms outer sphere complexes. The difference of complexation mechanisms between humic acids $\mathrm{F}$ and $\mathrm{T}$ can be related to differences in their structure as indicated by ${ }^{13} \mathrm{C}-\mathrm{NMR}$ spectroscopy.
\end{abstract}

\section{INTRODUCTION}

Soils are the most significant sink for trace elements released in the environment. It is now widely admitted that the toxicity of metals depends not only on their total concentration, but mainly on their chemical form, i.e. their speciation. Humic substances (HS) possess a polyfunctional (with $\mathrm{O}, \mathrm{N}$, and S-containing groups), polyelectrolytic and hydrophilic character, and the capacity to form intermolecular associations, and to change their spatial conformation [2]. Due to these characteristics, they can form stable complexes with metals. Despite the sustained interest of this topic for many years, much remains unknown regarding mechanistic aspects of the complexation. Several models have been proposed, including the formation of inner and outer sphere complexes [1]. In the present study, the complexation mechanism of $\mathrm{Zn}$ as a function of the metal concentration was investigated in two humic acids (HA) differing by the nature and/or proportion of their functional groups. Because of its versatile structural chemistry, $\mathrm{Zn}$ is a very good candidate for probing the different functional groups of HS that are likely to complex metals.

\section{EXPERIMENTAL}

Two HA were studied, one originating from a french soil [5], (T), and a reference materiel supplied by Fluka. They were extracted following the standardized International Humic Substances Society recipe [6]. ${ }^{13} \mathrm{C}-\mathrm{NMR}$ analysis showed that the two HA are structurally different: T HA contains predominantly aromatic, and F HA aliphatic functional groups. Zn complexation was carried out at pH 5 by placing the humic acid in a dialysis membrane (Spectrapor 6 for $\mathrm{PM} 1000$ ), $\mathrm{Zn}\left(\mathrm{NO}_{3}\right)_{2}$ being in the external solution. The system was stirred for 24 hours, and the absence of aqueous $\mathrm{Zn}$ at the end of the reaction was verified by ICP-AES. $\mathrm{Zn}$-HA complexes were then freeze-dried for EXAFS experiments. EXAFS measurements were performed on the CRG/IF beamline ID32 bending magnet at the European Synchrotron Radiation Facility (ESRF) in Grenoble. Zn K-edge spectra for diluted samples were recorded at room temperature in fluorescence detection mode using a 5-element Ge detector having a total counting rate of $350000 \mathrm{ph} / \mathrm{s}$. For each sample 3-6 scans were collected and averaged. EXAFS spectra for concentrated HA and references were measured in transmission mode. Interatomic distances and coordination numbers (CN) were calculated by using experimental phase shift and amplitude functions extracted from ZnO [7] (Tab. I).

\section{RESULTS AND DISCUSSION}

\subsection{Reference Compounds}

The sensitivity of the method to different coordination chemistries will be examplified with anhydrous $\mathrm{Zn}$ acetate, where $\mathrm{Zn}$ is 4-fold coordinated $\left({ }^{I V} \mathrm{Zn}\right)$ to four monodentate carboxyls $(d(\mathrm{Zn}-\mathrm{O})=1.973$ and $1.992 \AA)$ [8], and aqueous $\mathrm{Zn}{ }^{2+}$, where it is fully solvated by six water molecules, $d(\mathrm{Zn}-\mathrm{O})=2.08-2.17 \AA$ [9]. These differences of site geometry are visualized on radial structure functions (RSFs) by a shift and change in amplitude of first RSFs peaks (Fig.1). Zn-O distances and CN determined by least squares fitting are in good agreement with cristallographic values (Tab. I). A systematic structural analysis of $\mathrm{Zn}$ organic and 


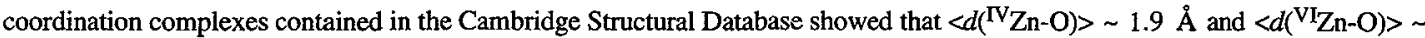
2.1 $\AA$. It is concluded from this analysis of reference compounds that the coordination site of $\mathrm{Zn}$ can be confidently inferred from bond length determination.

Table I: EXAFS and XRD structural parameter

\begin{tabular}{|c|c|c|c|c|c|c|c|c|}
\hline & \multirow[b]{2}{*}{ atomic pair } & \multicolumn{2}{|l|}{ XRD } & \multicolumn{4}{|c|}{ EXAFS } & \multirow[b]{2}{*}{$\begin{array}{c}\text { weighted } \\
\text { distance }(\AA)\end{array}$} \\
\hline & & $R(\AA)$ & $\mathbf{N}$ & $\mathbf{R}(\AA)$ & $\mathbf{N}$ & $\begin{array}{l}\Delta \sigma \\
(\AA)\end{array}$ & $\begin{array}{c}\Delta \mathrm{E} \\
(\mathrm{eV})\end{array}$ & \\
\hline \multicolumn{9}{|l|}{ sample } \\
\hline \multirow[t]{2}{*}{ Relerence: $\mathrm{ZnO}$} & $\mathrm{Zn}-\mathrm{O}$ & 1.973 & 3 & 1.98 & 4 & 0 & 0 & 1.93 \\
\hline & $\mathrm{Zn}-\mathrm{O}$ & 1.992 & 1 & & & & & \\
\hline Anhydrous Zn acetate & $\mathrm{Zn} \cdot \mathrm{O}$ & 1.949 & 1 & 1.97 & 4 & 0.01 & 0.64 & 1.97 \\
\hline \multirow[t]{3}{*}{ monoclinic } & $\mathrm{Zn}-\mathrm{O}$ & 1.952 & 1 & & & & & \\
\hline & $\mathrm{Zn}-\mathrm{O}$ & 1.96 & 1 & & & & & \\
\hline & $\mathrm{Zn}-\mathrm{O}$ & 1.965 & 1 & & & & & \\
\hline \multirow[t]{2}{*}{$\mathrm{Zn}$ in aqueous solution } & $\mathrm{Zn}-\mathrm{H}_{2} \mathrm{O}$ & $2.08-2.17$ & 6 & 2.07 & 42 & 0 & 0 & 2.11 \\
\hline & & & & 22 & 2 & 0 & & \\
\hline \multirow[t]{2}{*}{ HA T $200 \mathrm{mg} / \mathrm{Kg} \mathrm{Zn}$} & $\mathrm{Zn}-\mathrm{O}$ & & & 2.03 & 3 & 0 & 0 & 2.07 \\
\hline & $\mathrm{Zn}-\mathrm{O}$ & & & 2.17 & 1.4 & 0 & 0 & \\
\hline \multirow[t]{2}{*}{ HA T $500 \mathrm{mg} / \mathrm{Kg} \mathrm{Zn}$} & $\mathrm{Zn}-\mathrm{O}$ & & & 2.05 & 3.1 & 0 & 0 & 2.06 \\
\hline & $\mathrm{Zn}-\mathrm{O}$ & & & 2.15 & 0.5 & 0 & 0 & \\
\hline \multirow[t]{2}{*}{ HA T $5000 \mathrm{mg} / \mathrm{Kg} \mathrm{Zn}$} & $\mathrm{Zn}-\mathrm{O}$ & & & 2.02 & 2.4 & 0 & 0 & 2.06 \\
\hline & $\mathrm{Zn}-\mathrm{O}$ & & & 2.17 & 1 & 0 & 0 & \\
\hline HA T $32 \mathrm{~g} / \mathrm{Kg} \mathrm{Zn}$ & $\mathrm{Zn}-\mathrm{O}$ & & & 2.06 & 1.8 & 0.01 & 0 & 2.06 \\
\hline \multirow[t]{2}{*}{ HA T $500 \mathrm{~g} / \mathrm{KgZn}$} & $\mathrm{Zn}-\mathrm{O}$ & & & 2.04 & 3.5 & 0.01 & 0 & 2.03 \\
\hline & $\mathrm{Zn}-\mathrm{O}$ & & & 2.16 & 1.6 & 0.01 & 0 & \\
\hline \multirow[t]{2}{*}{ HAF $1000 \mathrm{mg} / \mathrm{Kg} \mathrm{Zn}$} & $\mathrm{Zn}-\mathrm{O}$ & & & 1.99 & 2.4 & 0 & 0 & 2.04 \\
\hline & $\mathrm{Zn}-\mathrm{O}$ & & & 2.10 & 1.8 & 0 & 0 & \\
\hline \multirow[t]{2}{*}{ HA F $5000 \mathrm{mg} / \mathrm{Kg} \mathrm{Zn}$} & $\mathrm{Zn}-\mathrm{O}$ & & & 1.98 & 2.3 & 0 & 0 & 2.03 \\
\hline & $\mathrm{Zn}-\mathrm{O}$ & & & 2.11 & 1.5 & 0 & 0 & \\
\hline \multirow[t]{2}{*}{ HA F $500 \mathrm{~g} / \mathrm{Kg} \mathrm{Zn}$} & $\mathrm{Zn}-\mathrm{O}$ & & & 2.03 & 3.1 & 0.01 & 0 & 2.07 \\
\hline & $\mathrm{Zn}-\mathrm{O}$ & & & 2.16 & 1.6 & 0.01 & 0 & \\
\hline
\end{tabular}

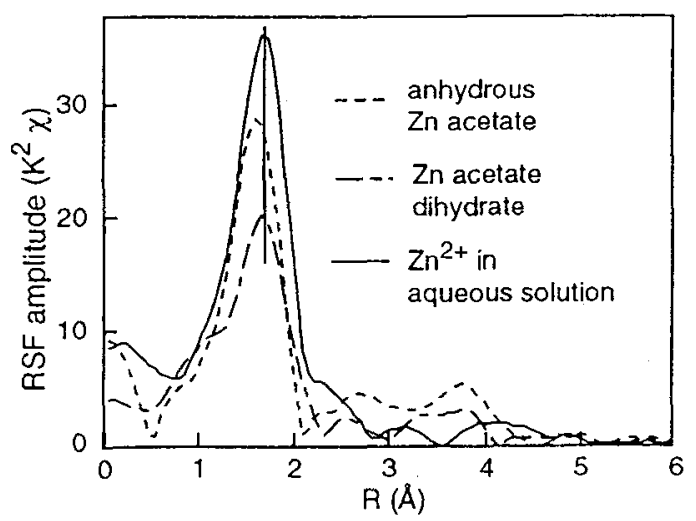

Figure 1: Comparaison of RSFs for $\mathrm{Zn}$ reference compounds.

\subsection{Zn Complexed Humic Acids}

Raw EXAFS spectra and RSFs for samples $F$ and $T$ as a function of $Z$ n concentration are contrasted in Fig. 2, 3, 4 and 5 . For sample $\mathrm{T}, \mathrm{Zn}-\mathrm{O}$ distances are typical of 6 -fold coordination regardless of the complexation rate. As the $\mathrm{Zn}$ concentration is raised, the amplitude of the first three peaks markedly decreases, except for the most concentrated sample. This is expressed in Table I by an apparent decrease of $\mathrm{CN}$ with increasing metal concentration down to 1.8 for the $32 \mathrm{~g} / \mathrm{Kg}$ sample. In the 300 $500 \mathrm{mg} / \mathrm{Kg}$ concentration range, the RSFs amplitude was found to be notably higher than in most reference spectra. This indicates that $\mathrm{Zn}$ is bound to structurally similar complexing sites, and that individual $\mathrm{Zn}-\mathrm{O}$ distances are coherent. The loss in amplitude when the $\mathrm{Zn}$ concentration is raised is interpreted by an increased distribution of complexing sites. As more $\mathrm{Zn}$ is 
added, new types of ligands would participate in the complexation, in the reverse order of their affinity for the metal. However, the highest concentrated sample $(500 \mathrm{~g} / \mathrm{Kg} \mathrm{Zn})$ does not follow this evolution. Its first RSF peak amplitude is very high, indicating that one $\mathrm{Zn}$ species predominates (Fig. 4). From comparison with aqueous $\mathrm{Zn}^{2+}$ (Fig. 6), it can be concluded that at high concentration, $\mathrm{Zn}$ forms predominantly an outer sphere complex. This interpretation is corroborated by cation exchange capacity (CEC) measurements. At pH 5, this capacity is between 175 to $260 \mathrm{meq}$ of charge/100g [3], i.e., 57 to $85 \mathrm{~g} / \mathrm{Kg} \mathrm{Zn}$. Thus, at $500 \mathrm{~g} / \mathrm{Kg} \mathrm{Zn}$, only 10 to $20 \%$ of total $\mathrm{Zn}$ can be bound to functional groups, the remaining being weakly bound by an outer sphere complexation mechanism. The fact that the $500 \mathrm{~g} / \mathrm{Kg}$ sample has a slightly lower $\mathrm{Zn}-\mathrm{O}$ amplitude than aqueous $\mathrm{Zn}^{2+}$ is probably due to the contribution of the minor inner sphere complexes, which represent 10 to $20 \%$ of total $\mathrm{Zn}$. The presence of an outer sphere complex at high metal concentration ( 5 to $50 \mathrm{wt}$. $\% \mathrm{Fe}^{3+}$ ) was also observed by $\mathrm{Mössbauer}$ spectroscopy in $\mathrm{Fe}^{3+} \mathrm{HA}$ complexes [10].

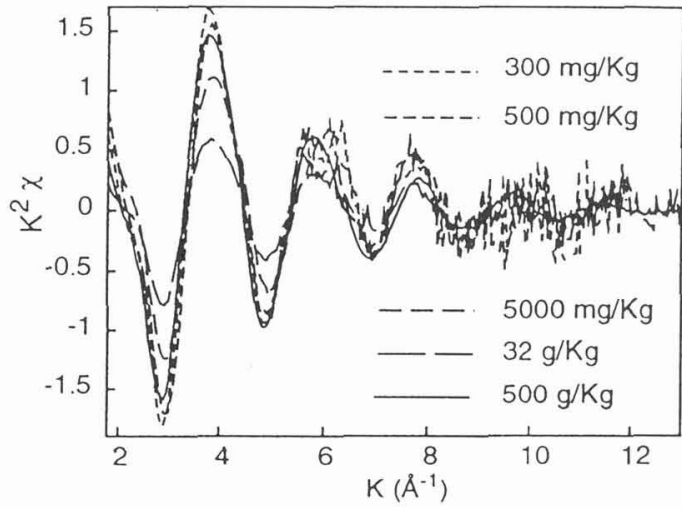

Figure 2: EXAFS spectra for $\mathrm{Zn}-\mathrm{T}$ humic acid complexes at different $\mathrm{Zn}$ concentrations.

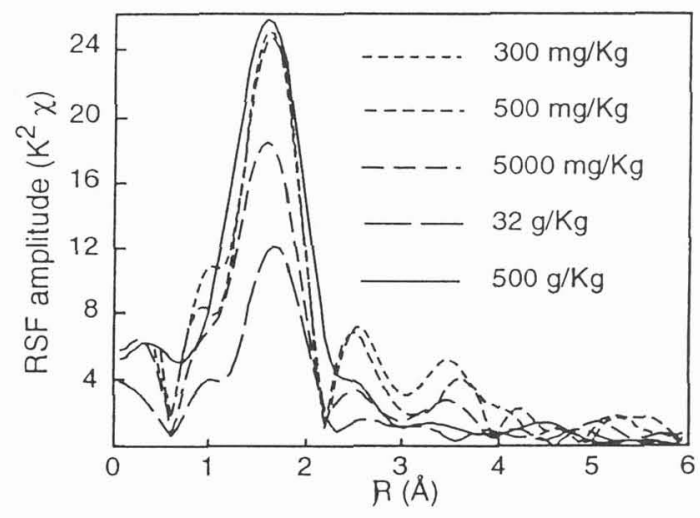

Figure 4: Comparaison of RSFs for $\mathrm{Zn}-\mathrm{T}$ humic acid complexes at different $\mathrm{Zn}$ concentrations.

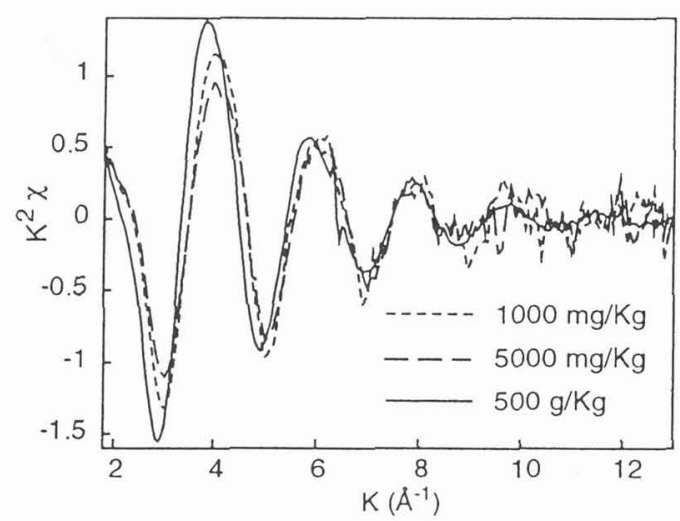

Figure 3: Exafs spectra for $\mathrm{Zn}-\mathrm{F}$ humic acid complexes at different $\mathrm{Zn}$ concentrations.

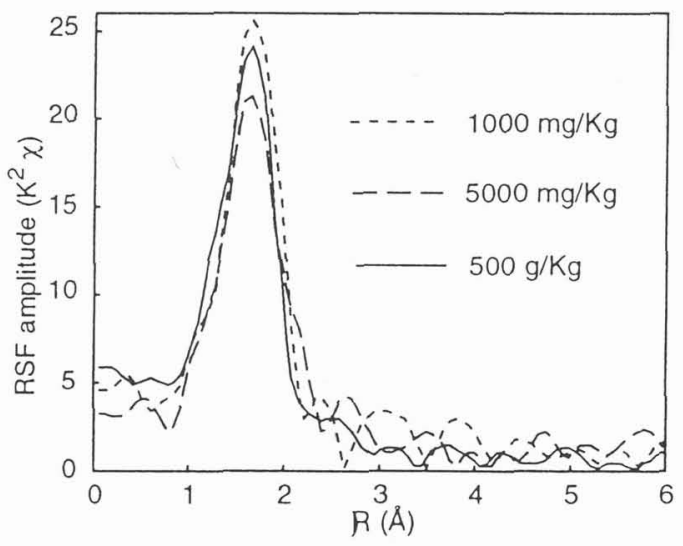

Figure 5: Comparaison of RSFs for $\mathrm{Zn}-\mathrm{F}$ humic acid complexes at different $\mathrm{Zn}$ concentrations.

The same amplitude evolution is observed for the $\mathrm{F}$ humic acid, but first shell $\mathrm{Zn}-\mathrm{O}$ distances are shorter (Tab. I, Fig. 5). Values typically lie between 4-fold and 6-fold coordination. This suggest a mixture of the two coordinations, the former prevailing at lower concentration. This interpretation agrees with the ESR study by Senesi et al. $[10]$ of $\mathrm{Fe}^{3+}-\mathrm{HA}$ at low Fe concentration $(2.8 \% \mathrm{Fe})$. They showed that part of the metal was bound to carboxylic and possibly phenolic groups as an inner sphere complex, in a tetrahedral and octahedral coordination. The present results show that tetrahedral configuration occurs only at very low $\mathrm{Zn}$ concentration. This 4 -fold coordination is generally achieved by four monodentate carboxyl groups, as in anhydrous $\mathrm{Zn}$ acetate.

\section{CONCLUSION}

At low concentration, $\mathrm{Zn}$ forms inner sphere complexes being either solely 6-fold (T) or 6-fold and 4-fold (F) coordinated to $O$ ligands. This difference in $\mathrm{Zn}$ site geometry observed for $\mathrm{HA} \mathrm{T}$ and $\mathrm{F}$ can be related to their differences in structure as indicated by ${ }^{13} \mathrm{C}$ NMR spectroscopy. As $\mathrm{Zn}$ concentration is raised, the number of different ligand sites increases, the coordination being 
exclusively octahedral. At very high metal concentrations, the major part of $\mathrm{Zn}(\mathbf{8 0 - 9 0 \% )}$ is bound as an outer sphere complex. Therefore, this study demonstrates the existence of a plurality of binding sites in HA, and thus provides a structural support to the use of a continuum of thermodynamic stability constants to model solution complexation experiments [11].

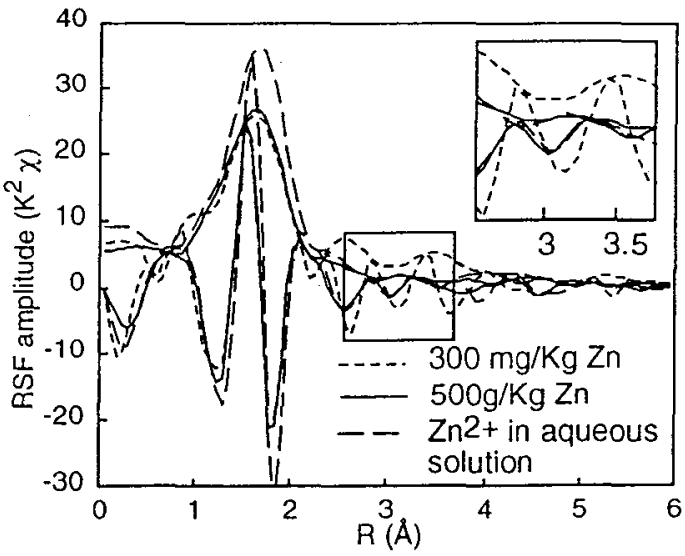

Figure 6: Comparaison of RSFs for $\mathrm{Zn}-\mathrm{T}$ humic acid complexes and $\mathrm{Zn}^{2+}$ in aqueous solutions.

\section{Acknowledgments}

The authors wish to thank the ESRF for making access to the facility.

\section{References}

[1] Senesi N., in Biogeochemistry of Trace elements Ed. (Lewis 1992) p. 429-496.

[2] Buffle J., in Metals Ions in Biological Systems, Vol 18, Circulation of metals in the environment, Sigel, H., Ed. (M. Dekker 1984) pp. 165-221.

[3] Stevenson, F. J., Humus Chemistry (Wiley 1994) pp. 378-404.

[4] Manceau A., Boisset M-C., Sarret G., Hazemann J-L, Mench M., Cambier Ph., Prost R., Env. Sci. \& Technol. 30 (1996) pp. 1540-1552.

[5] Arrouays D., Baize D., Hardy M., Le Lay C., Sciences du sol, Vol. 30, 4, (1994) pp. 227-247.

[6] Thurman E. M., in Humic Substances and Their Role in the Environment, Frimmel F. H. and Christman R. F., (Wiley 1988) pp. 31-43.

[7] Albertsson J., Abrahams S. C., Kvick A., Acta Cryst. B 45 (1989) 34-40.

[8] Clegg W., Little I. R., Straughan B. P., Acta Cryst., C 42 (1986) 1701.

[9] Burgess J. Ions in Solution (Ellis Horwood Ltd 1988) pp. 36-44.

[10] Senesi N., Griffith S. M., Schnitzer M., Townsend M. G., Geochim. et Cosmochim. Acta 41 (1977) $1131-1138$.

[11] Benedetti M F, Milne C J, Kinnigburgh D G, Van Riemsdijk W H, Koopal L K, Env. Sci. \& Technol., 29, (1995) pp. 446-457. 